\title{
Sistem Pendukung Keputusan Menentukan Prioritas Perbaikan Sarana Dan Prasarana Sekolah Dasar Di Kota Binjai Menggunakan Metode Moora
}

\author{
Meli Alisia ${ }^{1}$, Budi Serasi Ginting ${ }^{2}$, Mili Alfhi Syari ${ }^{3}$ \\ ${ }^{123)}$ STMIK Kaputama \\ J1. Veteran No. 4A-9A, Binjai, Sumatera Utara, Telp: (061)8828840, Fax: (061)882845 \\ E-mail: *1melialisia1411@gmail.com, ${ }^{2}$ budiserasiginting910@gmail.com, ${ }^{3}$ milli.alfhisyari@yahoo.co.id
}

\begin{abstract}
Abstrak
Sarana dan Prasarana Sekolah sangat penting dalam menunjang ilmu. Pengambilan keputusan selalu berkaitan dengan ketidak pastian dari hasil yang diambil. Sistem Pendukung keputusan dikembangkan untuk mengurangi faktor ketidak pastian tersebut dengan mengolah sebuah informasi menjadi sebuah alternatif pemecahan suatu masalah. Metode yang dapat diterapkan dalam sistem pendukung keputusan yaitu Multi-objective optimization on the basic of ratio analisys (MOORA). Untuk mengetahui proses pengolahan informasi sistem pendukung keputusan dengan menggunakan metode MOORA penulis menggunakan studi kasus menentukan pemilihan sarana dan prasarana dengan kriteria jumlah PTK, jumlah siswa , jumlah guru, jenis sarana dan prasarana, kerusakan, jumlah kelas, jumlah laboratorium, dan jumlah perpustakaa, serta 160 (seratus enam puluh) sekolah dasar di kota Binjai yang digunakan. Setelah semua nilai kriteria dimasukkan maka hasil pengolahan dengan metode MOORA akan diranking dan ranking tertinggi yang akan dipilih. Hasil perankingan dari alternatif yang digunakan bahwa SD AL FITIYAH termasuk kedalam pemilihan sarana dan prasarana memiliki nilai terbesar pada A55 dengan ranking 1.
\end{abstract}

Kata Kunci: MOORA, Pemilihan Sarana dan Prasarana, Sistem Pendukung Keputusan.

\begin{abstract}
School facilities and infrastructure are very important in supporting science. Decision making is always related to the uncertainty of the results taken. Decision support systems were developed to reduce the uncertainty factor by processing information into an alternative solution to a problem. The method that can be applied in decision support systems is Multi-objective optimization on the basic of ratio analysis (MOORA). To find out the information processing process of decision support systems using the MOORA method the author uses a case study to determine the selection of facilities and infrastructure with the criteria for the number of PTK, number of students, number of teachers, types of facilities and infrastructure, damage, number of classes, number of laboratories, and number of libraries, as well as 160 (one hundred and sixty) primary schools in the city of Binjai are used. After all the criteria values are entered, the processing results using the MOORA method will be ranked and the highest ranking will be selected. The results of the ranking of the alternatives used are that SD AL FITIYAH is included in the selection of facilities and infrastructure which has the greatest value on A55 with rank 1.
\end{abstract}

Keywords: Facilities and Infrastructure Selection, MOORA, Decision Support System.

\section{PENDAHULUAN}

Bangunan sekolah merupakan salah satu fasilitas publik yang mempunyai fungsi amat penting, oleh karenanya bangunan sekolah ini perlu mendapatkan perhatian yang serius dalam hal pemeliharaan dan perawatan, khususnya dalam jenjang pendidikan sekolah dasar. Hal ini karena sarana dan prasarana kurang memadai sehingga menimbulkan rasa kurang nyaman. 
Pendidikan di kota Binjai memerlukan beberapa elemen sebagai penunjang kelancaran proses pendidikan. Di antaranya elemen bangunan sekolah, ruang kelas, meja kursi serta alat-alat dan media pengajaran. Untuk mengetahui elemen-elemen sarana dan prasarana di pendidikan, maka perlu adanya sebuah sistem pendukung keputusan sekolah dasar mana yang segera direkonstruksi, untuk mengetahui yang belum memenuh syarat pada sarana pendidikan yang layak.

Permasalahan yang di hadapi pihak Dinas Pendidikan adalah memilih prioritas perbaikan sarana dan prasaran sekolah dasar dengan tepat, karena kebutuhan akan sarana dan prasaranan dalam pendidikan sekolah dasar yang kurang baik dan pemilihan masih secara manual sehingga membutuhkan waktu yang lama dan seiring dengan perjalannya waktu dan perkembangan kemajuan ilmu Pengetahuan Dan Teknologi (IPTEK), maka perlu di bangun sebuah sistem pendukung keputusan di harapkan dapat mempermudah pihak manajemen mengambil keputusan dalam memilih prioritas perbaikan sarana dan prasarana sekolah dasar di Dinas Pendidikan Kota Binjai dengan mengamati persoalan diatas Sistem Pendukung Keputusan dengan Metode "Multi - Objective Optimization on The Basic Of Ratio Analisys" (MOORA) dapat menentukan prioritas perbaikan sarana dan prasarana. Berdasarkan hasil penelitian dan pembahasan dapat disimpulkan hal-hal sebagai berikut : tujuan dari penelitian ini adalah Untuk merancang dan membangun sebuah sistem yang dapat digunakan untuk menentukan prioritas perbaikan sarana dan prasarana sekolah dasar.

\section{METODE PENELITIAN}

\subsection{Sistem Pendukung Keputusan}

Sistem pendukung keputusan adalah bagian dari sistem informasi berbasis komputer termasuk sistem berbasis pengetahuan atau manajemen pengetahuan yang dipakai untuk mendukung pengembalian keputusan dalam satu organisasi atau perusahaan. Dapat juga dikatakan sebagai sistem komputer yang mengolah data menjadi informasi untuk mengambil keputusan dari masalah semi terstruktur yang spesifik. Dan merupakan sistem yang membantu pengambil keputusan untuk melengkapi informasi dari data yang telah diolah secara relevan dan diperlakukan untuk membuat keputusan tentang suatu masalah dengan lebih tepat dan akurat.

Menurut Kusrini (2009, h. 15) Sistem Pendukung Keputusan atau (Decision Suport System) secara umum didefinisikan sebagai "sebuah sistem yang mampu memberikan kemampuan baik, kemampuan pemecahan masalah, maupun kemampuan berkomunikasi untuk masalah semi-terstruktur". Secara khusus, Sistem Pendukung Keputusan didefinisikan sebagai sebuah sistem yang mendukung kerja seorang manager dalam memecahkan masalah semi-terstuktur dengan cara memberikan informasi ataupun usulan menuju pada keputusan tertentu.

\subsection{Sarana dan Prasarana}

Pelaksanaan pendidikan nasional harus menjamin pemerataan dan peningkatan mutu pendidikan di tengah perubahan global agar warga Indonesia menjadi cerdas, Produktif dan berdaya saing tinggi dalam Nasional maupun Internasional. Untuk menjamin tercapainya tujuan pendidikan tersebut, pemerintahan telah mengamanatkan penyusunan delapan standar nasional pendidikan sebagaimana diatur dalam peraturan pemerintah Republik Indonesia No. 19 Tahun 2005 tentang standar Nasional Pendidikan.

Standart nasional pendidikan adalah kriteria minimum tentang sistem pendidikan di seluruh wilayah hukum negara kesatuan Republik Indonesia. Untuk menjamin terwujudnya hal tersebut, diperlukan adanya sarana dan prasaranan yang memadai. Dalam pengertiannya, sarana adalah perlengkapan pembelajaran yang dapat dipindah-pindah. Adapun prasarana adalah fasilitas dasar untuk menjalankan fungsi sekolah. Sarana dan prasarana tersebut harus memenuhi ketentuan minimum yang ditetapkan dalam standar sarana dan prasarana. Standar sarana dan prasarana ini ditujukan untuk lingkup pendidikan formal, jenis pendidikan umum, jenjang pendidikan dasar dan menegah.

\subsection{Multi - Objective Optimization on the basis of Ratio Analysis (MOORA)}


Menurut penelitian tentang penerapan metode Multi-Objective Optimization on the basis of Ratio Analysis (MOORA) dalam sistem pendukung keputusan penentuan kadar minyak mentah oleh (Agung et al., 2020), diperoleh prosedur dalam metode MOORA terdiri dari beberapa tahap yaitu:

1. Pembentukan matriks, dengan menggunakan rumus :

$$
x_{i j}=\left[\begin{array}{ccccc}
x_{11} & \cdots & x_{12} & \cdots & x_{1 n} \\
\vdots & \ddots & \vdots & \ddots & \vdots \\
x_{21} & \cdots & x_{22} & \cdots & x_{2 n} \\
\vdots & \ddots & \vdots & \ddots & \vdots \\
x_{m 1} & \cdots & x_{m 2} & \cdots & x_{m n}
\end{array}\right]
$$

2. Menentukan matriks normalisasi, dengan rumus :

$$
\begin{aligned}
& y_{i}=\sum_{j=1}^{g} W_{j} X_{i j}-\sum_{j=g+1}^{n} W_{j} X_{i j} \\
& \bar{x}_{i j}=\frac{x_{i j}}{\sum_{j=1}^{m} x^{2} i j} \ldots \ldots \ldots \ldots \ldots \ldots \ldots \ldots \ldots \ldots \ldots \ldots \ldots
\end{aligned}
$$

3. Menentukan nilai preferensi, dengan menggunakan rumus :

$$
y_{i}=\sum_{j=1}^{g} W_{j} X_{i j}-\sum_{j=g+1}^{n} W_{j} X_{i j}(j=1,2, n)
$$

\section{HASIL DAN PEMBAHASAN}

Dalam metode (MOORA) terdapat kriteria-kriteria yang akan dijadikan bahan perhitungan pada

\begin{tabular}{|c|c|c|c|c|c|c|c|c|c|c|}
\hline No & 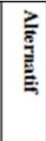 & Nama Sekolah & 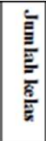 & 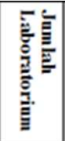 & 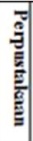 & 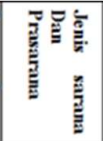 & 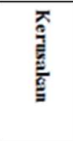 & 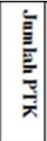 & 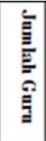 & 产 \\
\hline 1 & A1 & $\begin{array}{l}\text { SD GREATWALL } \\
\text { PRIME SCHOOL }\end{array}$ & 9 & 2 & 1 & Kesenian & Berat & 6 & 14 & 103 \\
\hline 2 & A2 & SD NEGERI 020251 & 10 & 0 & 0 & Gedung & Ringan & 20 & 18 & 379 \\
\hline 3 & A3 & SD NEGERI 020254 & 10 & 1 & 1 & Membelair & Berat & 11 & 16 & 311 \\
\hline 4 & A4 & SD NEGERI 023891 & 6 & 0 & 1 & \begin{tabular}{|l|} 
Pagar \\
Sekolah
\end{tabular} & Berat & 10 & 12 & 134 \\
\hline 5 & A5 & SD NEGERI 023892 & 6 & 0 & 1 & Membelair & Ringan & 11 & 7 & 82 \\
\hline \begin{tabular}{|l}
6 \\
\end{tabular} & A6 & SD NEGERI 023910 & 6 & 0 & 0 & Gedung & Berat & 9 & 6 & 60 \\
\hline 7 & A7 & SD NEGERI 023972 & 8 & 1 & 1 & Membelair & Sedang & 10 & 9 & 138 \\
\hline s & As & SD NEGERI 024764 & 6 & 0 & 0 & $\begin{array}{l}\text { Ruang } \\
\text { Kelas }\end{array}$ & Berat & 4 & 8 & 49 \\
\hline 9 & A9 & SD NEGERI 024765 & 6 & 0 & 0 & Membelair & Sedang & 5 & 6 & 44 \\
\hline 10 & $\begin{array}{l}\text { A1 } \\
0\end{array}$ & SD NEGERI 024766 & 6 & 1 & 1 & $\begin{array}{l}\text { Pagar } \\
\text { Sekolah }\end{array}$ & Berat & 11 & 10 & 86 \\
\hline
\end{tabular}
proses penilaian. Hal ini dimaksudkan untuk menentukan proses penerimaan perbaikan sarana dan prasarana. Dalam hal ini dibutuhkan kriteria-kriteria yang terlihat pada tabel 1.

Tabel 1 Kriteria

Tabel 2 Kriteria 


\begin{tabular}{|l|l|l|l|}
\hline Kriteria & Keterangan & Bobot & Jenis \\
\hline C1 & Jumlah Kelas & 0,15 & Benefit \\
\hline C2 & Jumlah Laboratorium & 0,15 & Benefit \\
\hline C3 & Perpustakaan & 0,10 & Benefit \\
\hline C4 & Jenis Sarana Dan Prasarana & 0,10 & Benefit \\
\hline C5 & Kerusakan & 0,10 & Benefit \\
\hline C6 & Jumlah PTK & 0,15 & Benefit \\
\hline C7 & Jumlah Guru & 0,10 & Benefit \\
\hline C8 & Jumlah Murid & 0,15 & Benefit \\
\hline
\end{tabular}

Pembobotan dari setiap kriteria adalah sebagai berikut :

Tabel 3 Pembobotan Jumlah PTK

\begin{tabular}{|l|l|l|}
\hline Jumlah PTK & Bobot & Nilai \\
\hline Lebih dari 30 PTK & Sangat Baik & 4 \\
\hline 20PTK - 29 PTK & Baik & 3 \\
\hline 11PTK - 19PTK & Cukup & 2 \\
\hline Kurang Dari 10 PTK & Buruk & 1 \\
\hline
\end{tabular}

Tabel 4 Pembobotan Jumlah Guru

\begin{tabular}{|l|l|l|}
\hline Jumlah Guru & Bobot & Nilai \\
\hline Lebih dari 30 Guru & Cukup & 4 \\
\hline 20Guru - 29 Guru & Cukup Baik & 3 \\
\hline 11Guru - 19Guru & Baik & 2 \\
\hline Kurang Dari 10 Guru & Sangat Baik & 1 \\
\hline
\end{tabular}

Tabel 5 Pembobotan Jumlah Siswa

\begin{tabular}{|l|l|l|}
\hline Jumlah Siswa & Bobot & Nilai \\
\hline Lebih Dari 300 siswa & Sangat Baik & 4 \\
\hline 200 siswa - 299 siswa & Baik & 3 \\
\hline 101 siswa - 199 siswa & Cukup Baik & 2 \\
\hline Lebih Kurang 100 siswa & Cukup & 1 \\
\hline
\end{tabular}

Tabel 6 Pembobotan Jumlah Kelas

\begin{tabular}{|l|l|l|}
\hline Jumlah Kelas & Bobot & Nilai \\
\hline Lebih Dari 10 kelas & Baik & 3 \\
\hline 5 kelas - 9 kelas & Cukup & 2 \\
\hline Lebih Kurang 5 kelas & Buruk & 1 \\
\hline
\end{tabular}

Tabel 7 Pembobotan Jumlah Laboratorium

\begin{tabular}{|l|l|l|}
\hline Jumlah Kelas & Bobot & Nilai \\
\hline$\geq 1$ & Baik & 2 \\
\hline 0 & Buruk & 1 \\
\hline
\end{tabular}

Tabel 8 Pembobotan Perpustakaan 


\begin{tabular}{|l|l|l|}
\hline Jumlah Kelas & Bobot & Nilai \\
\hline 1 & Baik & 2 \\
\hline 0 & Buruk & 1 \\
\hline
\end{tabular}

Tabel 9 Pembobotan Sarana Dan Prasarana

\begin{tabular}{|l|l|l|}
\hline $\begin{array}{l}\text { Jenis Sarana dan } \\
\text { Prasarana }\end{array}$ & Bobot Nilai \\
\hline Ruang kelas & Sangat Baik & 5 \\
\hline Pagar Sekolah & Baik & 4 \\
\hline Meubelair & Cukup & 3 \\
\hline Kesenian & Buruk & 2 \\
\hline Gedung & Sangat Buruk & 1 \\
\hline
\end{tabular}

Tabel 10 Pembobotan Kerusakan

\begin{tabular}{|l|l|l|}
\hline Kerusakan & Bobot & Nilai \\
\hline Ringan & Baik & 1 \\
\hline Sedang & Cukup & 2 \\
\hline Berat & Tidak Baik & 3 \\
\hline
\end{tabular}

Berdasarkan data dari kriteria yang ada maka dihasilkan rating kecocokan dari setiap alternatif, seperti pada tabel berikut ini:

Tabel 12 Rating Kecocokan

\begin{tabular}{|l|l|l|l|l|l|l|l|l|}
\hline Alternatif & C1 & C2 & C3 & C4 & C5 & C6 & C7 & C8 \\
\hline A1 & 2 & 2 & 2 & 2 & 3 & 1 & 2 & 2 \\
\hline A2 & 2 & 1 & 1 & 1 & 1 & 3 & 2 & 4 \\
\hline A3 & 3 & 1 & 2 & 3 & 3 & 2 & 2 & 4 \\
\hline A4 & 2 & 1 & 2 & 4 & 3 & 1 & 2 & 2 \\
\hline A5 & 2 & 1 & 2 & 3 & 1 & 2 & 1 & 1 \\
\hline A6 & 2 & 1 & 1 & 1 & 3 & 1 & 1 & 1 \\
\hline A7 & 2 & 1 & 2 & 3 & 2 & 1 & 1 & 2 \\
\hline A8 & 2 & 1 & 1 & 5 & 3 & 1 & 1 & 1 \\
\hline A9 & 2 & 1 & 1 & 3 & 2 & 1 & 1 & 1 \\
\hline A10 & 2 & 1 & 2 & 4 & 3 & 2 & 1 & 1 \\
\hline Optimum & + & + & + & + & + & + & & + \\
\hline
\end{tabular}

Dari hasil rating kecocokan maka dapat dihasilkan matriks $\mathrm{x}$ : 


$$
X=\left[\begin{array}{llllllll}
2 & 2 & 2 & 2 & 3 & 1 & 2 & 2 \\
2 & 1 & 1 & 1 & 1 & 3 & 2 & 4 \\
3 & 1 & 2 & 3 & 3 & 2 & 2 & 4 \\
2 & 1 & 2 & 4 & 3 & 1 & 1 & 2 \\
2 & 1 & 2 & 3 & 1 & 2 & 1 & 1 \\
2 & 1 & 1 & 1 & 3 & 1 & 1 & 1 \\
2 & 1 & 2 & 3 & 2 & 1 & 1 & 2 \\
2 & 1 & 1 & 5 & 3 & 1 & 1 & 1 \\
2 & 1 & 1 & 3 & 2 & 1 & 1 & 1 \\
2 & 1 & 2 & 4 & 3 & 2 & 1 & 1
\end{array}\right]
$$

Kemudian dilakukan normalisasi terhadap matriks X :

$$
\begin{aligned}
& \mathrm{C} 1=\sqrt{2+2^{2}+3^{2}+2^{2}+2^{2}+2^{2}+2^{2}+2^{2}+2^{2}+2^{2}} \\
& =\sqrt{4+4+9+4+4+4+4+4+4+4} \\
& \quad=\sqrt{45}=6,7082 \\
& \mathrm{~A}_{11}=2 / 6,7082=0,2981 \\
& \mathrm{~A}_{21}=2 / 6,7082=0,2981 \\
& \mathrm{~A}_{31}=3 / 6,7082=0,4472 \\
& \mathrm{~A}_{41}=2 / 6,7082=0,2981 \\
& \mathrm{~A}_{51}=2 / 6,7082=0,2981 \\
& \mathrm{~A}_{61}=2 / 6,7082=0,2981 \\
& \mathrm{~A}_{71}=2 / 6,7082=0,2981 \\
& \mathrm{~A}_{81}=2 / 6,7082=0,2981 \\
& \mathrm{~A}_{91}=2 / 6,7082=0,2981 \\
& \mathrm{~A}_{101}=2 / 6,7082=0,2981 \\
& \\
& \mathrm{C}_{2}=\sqrt{2^{2}+12}+1^{2}+1^{2}+1^{2}+1^{2}+1^{2}+1^{2}+1^{2}+1^{2} \\
& \quad=\sqrt{4+1+1+1+1+1+1+1+1+1} \\
& \quad=\sqrt{13}=3,6055 \\
& \mathrm{~A}_{12}=2 / 3,6055=0,5547 \\
& \mathrm{~A}_{22}=1 / 3,6055=0,2774 \\
& \mathrm{~A}_{32}=1 / 3,6055=0,2774 \\
& \mathrm{~A}_{42}=1 / 3,6055=0,2774 \\
& \mathrm{~A}_{52}=1 / 3,6055=0,2774 \\
& \mathrm{~A}_{62}=1 / 3,6055=0,2774 \\
& \mathrm{~A}_{72}=1 / 3,6055=0,2774 \\
& \mathrm{~A}_{82}=1 / 3,6055=0,2774 \\
& \mathrm{~A}_{92}=1 / 3,6055=0,2774 \\
& \mathrm{~A}_{102}=1 / 3,6055=0,2774 \\
& \mathrm{C}_{3}=\sqrt{2^{2}+12}+2^{2}+2^{2}+2^{2}+1^{2}+2^{2}+1^{2}+1^{2}+2^{2} \\
& \quad=\sqrt{4+1+4+4+4+1+4+1+1+4} \\
& \quad=\sqrt{28}=5,2915 \\
& \mathrm{~A}_{13}=2 / 5,2915=0,378 \\
& \mathrm{~A}_{23}=1 / 5,2915=0,189 \\
& \mathrm{~A}_{33}=2 / 5,2915=0,378 \\
& \mathrm{~A}_{43}=2 / 5,2915=0,378 \\
& \mathrm{~A}_{53}=2 / 5,2915=0,378 \\
& \mathrm{~A}_{63}=1 / 5,2915=0,189 \\
& \mathrm{~A}_{73}=2 / 5,2915=0,378 \\
& \mathrm{~A}_{83}=1 / 5,2915=0,189 \\
& \mathrm{~A}_{93}=1 / 5,2915=0,189 \\
&
\end{aligned}
$$




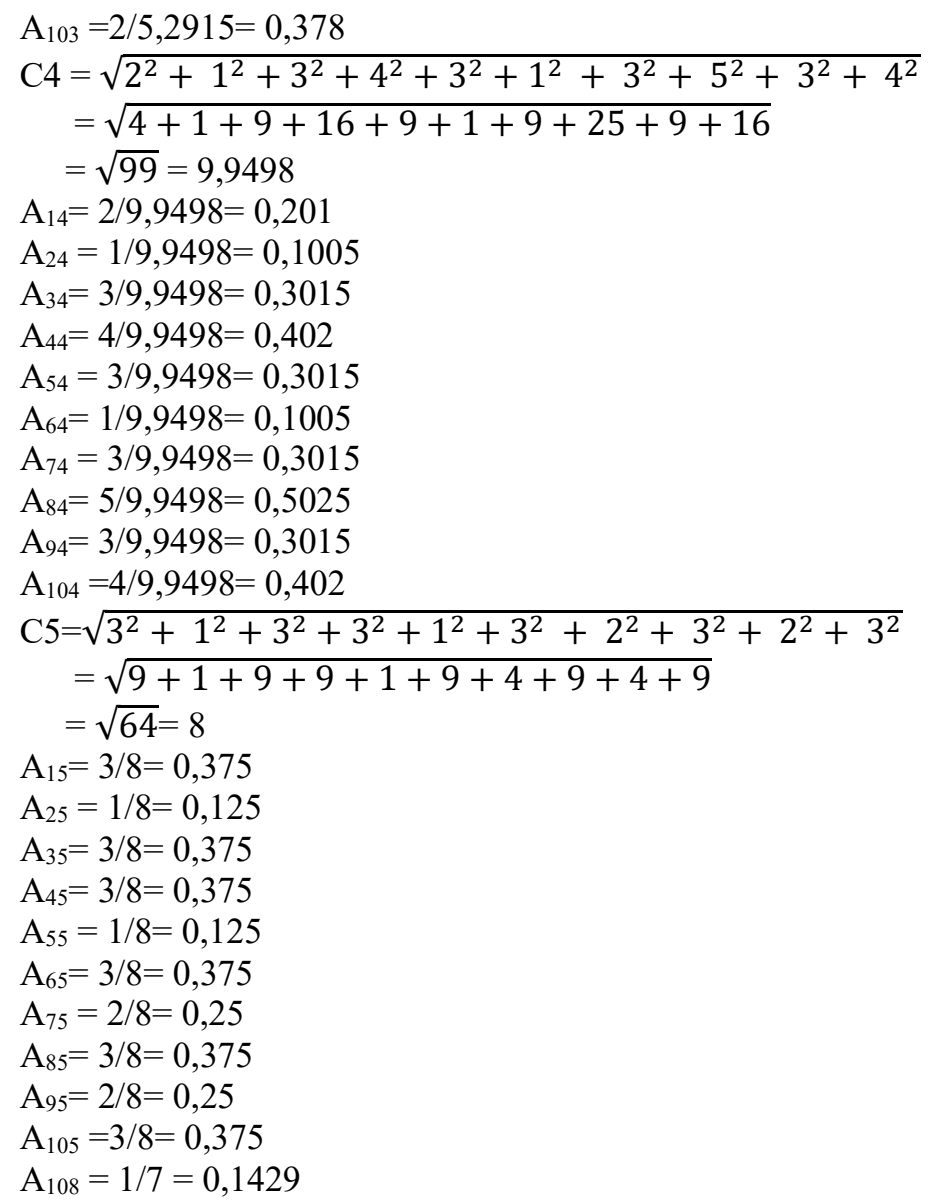

Hasilnya dari normalisasi matriks $\mathrm{X}$ diperoleh matriks $\mathrm{X}_{\mathrm{ij}}^{*}$ dilihat berikut ini.

$\mathrm{X}_{\mathrm{ij}}^{*}=$

$\left[\begin{array}{cccccccc}0,2981 & 0,5547 & 0,378 & 0,201 & 0,375 & 0.1925 & 0,4264 & 0,2857 \\ 0.2981 & 0,2774 & 0,189 & 0,1005 & 0,125 & 0.5774 & 0,4264 & 0,5714 \\ 0,4472 & 0,2774 & 0,378 & 0,3015 & 0,375 & 0.3849 & 0,4264 & 0,5714 \\ 0,2981 & 0,2774 & 0,378 & 0,402 & 0,375 & 0.1925 & 0,4264 & 0,2857 \\ 0,2981 & 0,2774 & 0,378 & 0,3015 & 0,125 & 0.3849 & 0,2132 & 0,1429 \\ 0,2981 & 0,2774 & 0,189 & 0,1005 & 0,375 & 0.1925 & 0,2132 & 0,1429 \\ 0,2981 & 0,2774 & 0,378 & 0,3015 & 0,25 & 0.1925 & 0,2132 & 0,3535 \\ 0,2981 & 0,2774 & 0,189 & 0,5025 & 0,375 & 0.1925 & 0,2132 & 0,1429 \\ 0,2981 & 0,2774 & 0,189 & 0,3015 & 0,25 & 0.1925 & 0,2132 & 0,1429 \\ 0,2981 & 0,2774 & 0,378 & 0,402 & 0,375 & 0.3849 & 0,2132 & 0,1429\end{array}\right]$

Mengoptimalkan atribut menyertakan bobot dalam pencarian yang ternormalisasi. Max merupakan kriteria jenis benefit dan min merupakan kriteria jenis cost.Padapenelitian ini hanya terdapat jenis kriteria benefit.

$Y_{1}=(0,2981 \times 0,15)+(0,5547 \times 0,15)+$ $(0,378 \times 0,10)+(0,201 \times 0,10)+$

$$
\begin{gathered}
(0,375 \times 0,10)+(0,1925 \times 0,15) \\
+(0,4264 \times 0,10)+(0,2857 \times 0,15)
\end{gathered}
$$

$$
=0,3377
$$

$Y_{2}=(0,2981 \times 0,15)+(0,2774 \times 0,15)+$

$(0,189 \times 0,10)+(0,1005 \times 0,10)+$

$$
(0,125 \times 0,10)+(05774 \times 0,15)+(0,4264 \times 0,10)+(0,5714 \times 0,15)
$$




$$
\begin{aligned}
= & 0,3427 \\
Y_{3}= & (0,4472 \times 0,15)+(0,2774 \times 0,15)+(0,378 \times 0,10)+(0,3015 \times 0,10)+ \\
& \quad(0,375 \times 0,10)+(0,3849 \times 0,15)+(0,4264 \times 0,10)+(0,5714 \times 0,15) \\
= & 0,4002 \quad(0,375 \times 0,10)+(0,1925 \times 0,15)+(0,4264 \times 0,10)+(0,2857 \times 0,15) \\
Y_{4}= & (0,2981 \times 0,15)+(0,2774 \times 0,15)+(0,378 \times 0,10)+(0,402 \times 0,10)+ \\
= & 0,3162 \quad(0,125 \times 0,10)+(0,3849 \times 0,15)+(0,2132 \times 0,10)+(0,1429 \times 0,15) \\
Y_{5}= & (0,2981 \times 0,15)+(0,2774 \times 0,15)+(0,378 \times 0,10)+(0,3015 \times 0,10)+ \\
= & 0,2673
\end{aligned}
$$

Tabel 13 Hasil Optimasi

\begin{tabular}{|l|l|}
\hline Alternatif & Hasil Optimasi \\
\hline A1 & \multicolumn{1}{|c|}{0,3377} \\
\hline A2 & 0,3427 \\
\hline A3 & 0,4002 \\
\hline A4 & 0,3162 \\
\hline A5 & 0,2673 \\
\hline A6 & 0,2244 \\
\hline A7 & 0,2723 \\
\hline A8 & 0,2646 \\
\hline A9 & 0,232 \\
\hline A10 & 0,3023 \\
\hline
\end{tabular}

Dari hasil diatas, dapat dilihat perangkingan setiap alternatif dari penerimaan perbaikan sarana dan prasarana pada tabel berikut :

Tabel 14 Hasil rangking

\begin{tabular}{|l|l|l|}
\hline Alternatif & Hasil & Rangking \\
\hline A3 & 0,4002 & 1 \\
\hline A2 & 0,3427 & 2 \\
\hline A1 & 0,3377 & 3 \\
\hline A4 & 0,3162 & 4 \\
\hline A10 & 0,3023 & 5 \\
\hline A7 & 0,2723 & 6 \\
\hline A5 & 0,2673 & 7 \\
\hline A8 & 0,2646 & 8 \\
\hline A9 & 0,232 & 9 \\
\hline A6 & 0,2244 & 10 \\
\hline
\end{tabular}

Hasil yang didapat adalah alternatif ke-3 (A3) merupakan alternatif yang memiliki nilai tertinggi dibanding dengan alternatif lainnya, yang berarti alternatif ke-3 (A3) merupakan alternatif yang terpilih.

\subsection{Pembahasan}

Pada penelitian ini sistem dibangun menggunakan bahasa pemrograman PHP dengan basis data MySQL, aplikasi sistem pendukung tersebut adalah sebagai berikut:

1. Tampilan Halaman Login 
Halaman login akan ditampilkan pertama kali sebelum pengguna masuk kedalam sistem. Pengguna dapat masuk kedalam sistem menggunakan username dan password yang dimiliki. Hasil dari implementasi halaman login dapat dilihat pada gambar berikut ini:

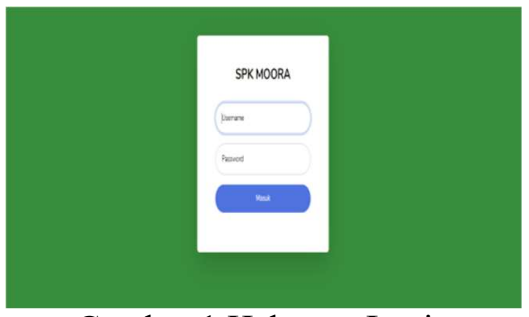

\section{Tampilan Halaman Beranda}

Gambar 1 Halaman Login

Setelah pengguna berhasil masuk kedalam sistem, pengguna akan diarahkan halaman beranda. Halaman ini adalah halaman utama yang menampilkan menu-menu yang dapat diakses oleh pengguna. Hasil dari implementasi halaman beranda dapat dilihat pada gambar berikut ini:
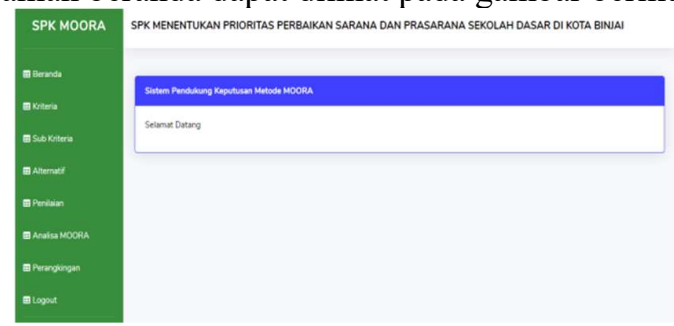

Gambar 2 Halaman Beranda

\section{Halaman Data Kriteria}

Pada halaman data kriteria, pengguna dapat menambah data kriteria serta melihat data kriteria yang sudah di input. Pengguna dapat menginput banyaknya kriteria yang diperlukan, Selain melakukan input data kriteria, pengguna juga dapat melakukan edit data jika ada kesalahan atau melakukan hapus data. Hasil dari implementasi halaman data kriteria dapat dilihat pada gambar berikut

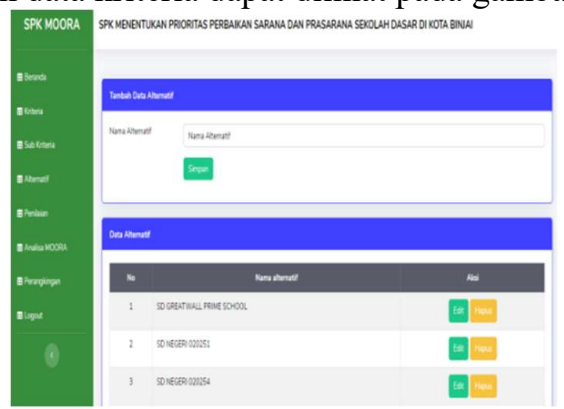

\section{Halaman Data Sub Kriteria}

Gambar 3 Halaman Data Kriteria

Pada halaman data sub kriteria, pengguna dapat menginput banyaknya sub kriteria yang diperlukan berdasarkan kriteria yang ada, Selain melakukan input data sub kriteria, pengguna juga dapat melihat data yg sudah di input serta melakukan edit data jika ada kesalahan atau melakukan hapus data. Tampilan dari halaman data sub kriteria adalah sebagai berikut:

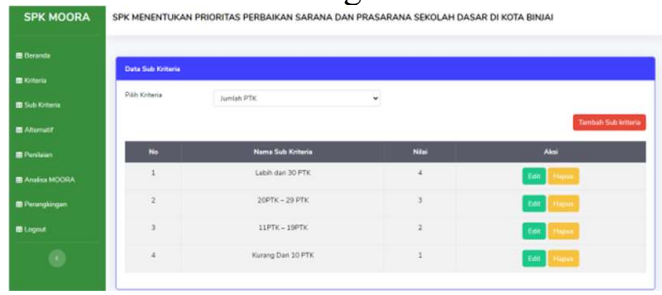

Gambar 4 Halaman Data Sub Kriteria

\section{Halaman Data Alternatif}


Pada tampilan halaman data alternatif, pengguna dapat menginput data alternatif. Selain melakukan input data alternatif, pengguna juga dapat melihat data yg sudah di input serta melakukan edit data jika ada kesalahan atau melakukan hapus data. Tampilan dari halaman altenatif adalah sebagai berikut:

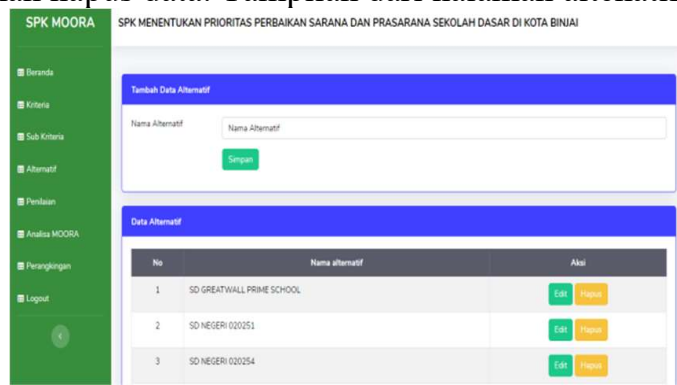

\section{Halaman Penilaian Alternatif}

Gambar 5 Halaman Data Alternatif

Halaman ini merupakan halaman saat petugas melakukan penilaian alternatif berdasarkan kriteria yang ada. Tampilan dari halaman penilaian alternatif adalah sebagai berikut :

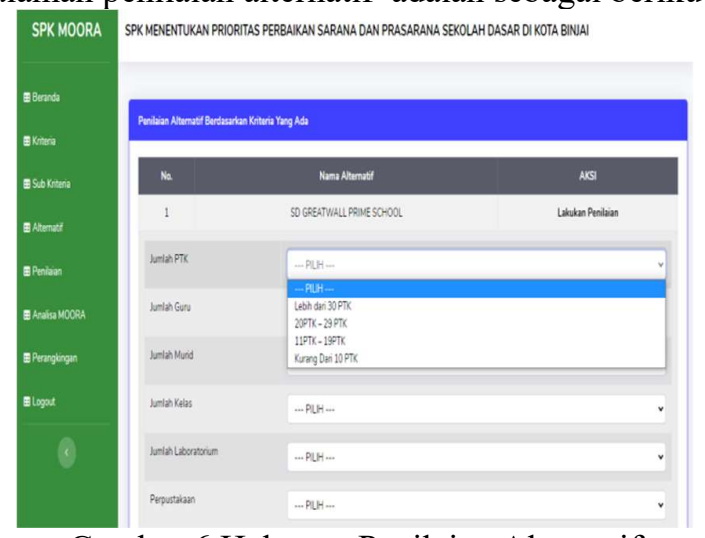

\section{Halaman Analisa Metode MOORA}

Gambar 6 Halaman Penilaian Alternatif

Pada halaman ini pengguna dapat melihat analisa dari metode MOORA. Tampilan dari halaman analisa MOORA adalah sebagai berikut :

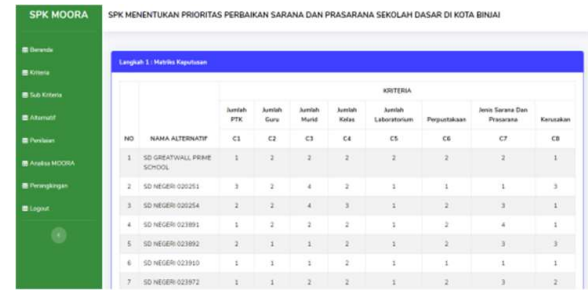

Gambar 7 Halaman Analisa MOORA

\section{Halaman Perangkingan}

Pada halaman ini pengguna dapat mengetahui rangking dari alternatif yang telah dihitung menggunakan metode MOORA serta dapat mencetak hasil analisa MOORA. Tampilan dari halaman perankingan adalah sebagai berkut : 


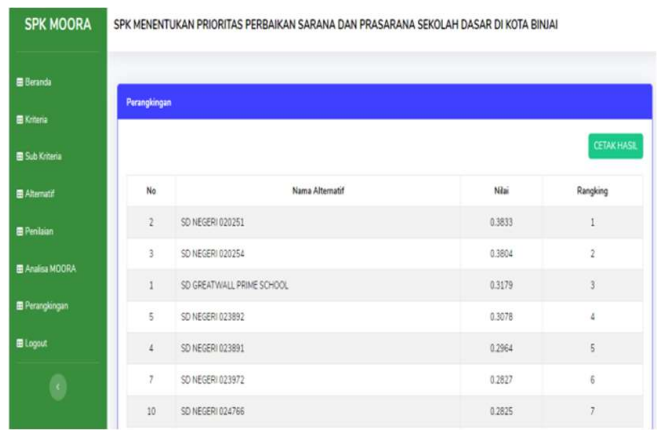

Gambar 8 Halaman Perangkingan

\section{KESIMPULAN} berikut :

Berdasarkan hasil analisis permasalahan yang di dapat, maka di ambil kesimpulan yaitu sebagai

1. Dengan dibangunnya sistem pendukung keputusan untuk menentukan prioritas perbaikan sarana dan prasarana sekolah dasar dengan metode MOORA akan lebih efektif dan efisiensi. Perbaikan sarana dan prasarana sekolah dasar yang dihasilkan dapat diterima oleh semua pihak dan tepat sasaran serta sistem pendukung keputusan ini akan meminimalisi kesalahan kesalahan dalam proses pemasukan data.

2. Berdasarkan hasil perhitungan dengan menggunakan metode MOORA yang telah dilakukan sebelumnya dari 160 sekolah dasar nilai $\mathrm{A}_{55}$ menunjukkan nilai yang terbesar yaitu 0,1185 sehingga alternatif $\mathrm{A}_{55}$ dalam jenis sarana dan prasarana sebagai Alternatif terbaik.

3. Penerapan algoritma MOORA dalam menentukan jenis sarana dan prasarana metode ini memiliki hasil akhir atau alternatif terbaik, dapat dikatakan kalau penggunaan metode ini dapat digunakan untuk menentukan prioritas perbaikan sarana dan prasarana sekolah dasar.

\section{SARAN}

Berdasarkan kesimpulan diatas, maka penulis dapat memberikan saran-saran yang kiranya dapat membantu penelitian dan pengembangan sistem ini. Saran-saran penulis dalam penelitian ini adalah sebagai berikut :

1. Dengan dilakukannya penilaian ini agar kedepannya sistem ini dapat dikembangkan lebih baik lagi, untuk meningkatkan efesiensi dari sistem ini.

2. Sistem dapat dijadikan bahan dalam pengembangan dan penelitian lebih lanjut, sehingga dapat memberikan manfaat lebih banyak lagi dan menghasilkan suatu sistem yang baru yang lebih baik dan interaktif.

3. Sistem Pendukung Keputusan menentukan prioritas perbaikan sarana dan prasarana sekolah dasar dengan metode MOORA ini dapat dikembangkan dengan metode berbeda.

\section{DAFTAR PUSTAKA}

[1]. Aldi Muharsyah, (2018), Pada Jurnal Riset Komputer (JURIKOM), Sistem Pendukung Keputusan Penerimaan Jurnalis Menerapkan Metode Multi Objective Optimization on The Basis of Ratio Analysis (MOORA)

[2]. Aldi, dkk (2018), Pada Jurnal Riset Komputer (JURIKOM) Teknik Informatika STMIK Budi Darma Medan, ISSN 2407-389X, Metode Multi-Objective Optimization on the basis of Ratio Analysis (MOORA)

[3]. Andi. 2012. Adobe Dreamweaver CS6 dan PHP - Mysql untuk pemula, Edisi Pertama, Yogyakarta, Andi Offest. 
[4]. Dwika Assrani, dkk. Jurnal Riset Komputer (JURIKOM), Vol.5 No.1, Bulan Februari 2018 Penentuan Penerimaan Bantuan Siswa Miskin Menerapkan Multi-Objective Optimization On The Basis Of Ratio Analysis (MOORA)

[5]. Kusrini. 2009. Konsep dan Aplikasi Sistem Pendukung Keputusan, Andi, Yogyakarta,

[6]. Mira Chandra Kirana (2016), Pada jurnal ilmiah Politeknik Batam p-ISSN : 2085-3858, Penerapan Analytical Hirearcy Process Pada Sistem Pendukung Keputusan Pengalokasian Anggaran Biaya Sarana dan Prasarana Sekolah

[7]. Muhamad Muslihudin, Dkk (2017). Pada jurnal STMIK Pringsewu Lampung, Sistem Pendukung Keputusan Penerima Kelayakan Rehap SMP Pada Dinas Pendidikan Kabubaten Priengsewu menggunakan Metode SAW

[8]. Nugroho (2011, h. 511), "kamus data merupakan salah satu bagian yang terintegritasi pada DBMS bertipe relasional yang penyimpanan data atau informasi mengenai basis data, termasuk namanama devinisi untuk setiap tabel pada basis data".

[9]. Utami, dkk. 2012. Sistem Basis Data Menggunakan Microsoft SQL Server 2005. Andi, Yogyakarta. 